\title{
Parvana's Trilogy: A Study of Violence toward Afghanistan Women and Girls
}

\author{
Hiqma Nur Agustina \\ Universitas Islam Syekh-Yusuf \\ hiqma@unis.ac.id, \\ Tenia Ramalia \\ Universitas Islam Syekh-Yusuf \\ tramalia@unis.ac.id
}

\begin{abstract}
:
Afghan women and girls became the portray of the victim of violence since several years ago. The news about the tragedy spread through the newspaper, printed and online, and also in the literature world. The exposure of their sufferings as the impact of war and conflict among the etnics on Taliban rezim reflected in the Parvana's Trilogy named The Breadwinner (2000), Parvana's Journey (2002), and Mud City (2003). These trilogy were written by Deborah Ellis. This research is intended to show how the women and girls became the worst victim which received violence caused by all of the triggers. This paper uses theory of violence and framing analysis to analyze those violences. The result of discussion shows that many efforts done by women and girls to overcome their difficult lives, such as pretending being boys, human trafficking, and living as refugees are the ways to survive.
\end{abstract}


Keywords: abuse, afghan women and girls, undercover, human trafficking, violence

\begin{abstract}
Abstrak:
Perempuan dewasa dan anak perempuan di Afghanistan menjadi gambaran korban kekerasan sejak bertahun-tahun yang lalu. Berita tentang tragedi ini tersebar melalui surat kabar, baik cetak maupun online, dan juga dalam karya sastra. Penjelasan tentang penderitaan mereka sebagai dampak perang dan konflik antar etnik pada pemerintahan rezim Taliban tercermin dalam Parvana Trilogynamed The Breadwinner (2000), Parvana's Journey (2002), dan Mud City (2003) yang ditulis oleh Deborah Ellis. Penelitian ini bertujuan untuk menunjukkan perempuan menjadi korban terbesar yang menerima kekerasan yang disebabkan oleh banyak hal. Memanfaatkan teori kekerasan dan analisis framing, artikel ini memotret dampak kekerasan yang dialami perempuan. Artikel ini menyimpulkan banyak upaya yang dilakukan oleh mereka untuk mengatasi hidup yang sulit, seperti berpura-pura menjadi anak lelaki, perdagangan manusia, dan hidup sebagai pengungsi sebagai cara untuk bertahan hidup.
\end{abstract}

Kata Kunci : Pelecehan, Perempuan dan Anak Perempuan Afganistan, Penyamaran, Perdagangan Manusia, Kekerasan.

\title{
A. INTRODUCTION
}

The blurry portraits of Afghan women and children are often displayed in conditions exposed to violence due to prolonged wars, ethnic conflicts and the Taliban regime's rule. Their deplorable depictions of condition, homelessness, joblessness and even depletion of food supplies into media consumption in different parts of the world. In one study, the most suffering victims of war atrocities in Afghanistan were children and women. More than 3,000 instances of violence were 
registered by Afghanistan Independent Human Rights Commission (AIHRC) in the first six months of the current Afghan year, which began on March 21, 2012 (Hasrat, 2012). Violence againts women is considered a widespread and undeniable reality in Afghanistan's society. The present report covers different types of violence against women in the first 6 months of the current year. Besides statistical information, the report also presents illustrative cases of violence that tell a horrendous reality. Not surprisingly, international media publications show the news about aspects of violence, human trafficking, and abuse being a major issue in the news on Afghanistan.

The role of the media in photographing various issues of violence and repression shows how massively negative the impact of this endless war. This essay will discuss the issue of violence experienced by Afghan women and children in the frame of media analysis that has a significant role. The presence of reality facts that reveal social problems in Afghan society is presented in three texts contained in Deborah Ellis's Parvana Trilogy. How the issue of violence experienced by Afghan women and children is promoted to show their physical and psychological suffering into this research. Media used as a tool to generate discussion of the research formulation is a novel trilogy as a result of observation and direct interviews of girls named Parvana.

An interest in gender studies and women led the researchers whose have done many studies takes the corpus of the novel Parvana Trilogy research entitled The Breadwinner(2000), Parvana'sJourney (2002), and Mud City (2003). These three novels are the work of Deborah Ellis. These three sources of data tell the episode of Parvana's development from the beginning of her ages in 11 years old and her friend named Shauzia. Many people have not understood the link between gender and sexuality that has created many gender imbalances in our society. Understanding that has not been properly understood is a bit much to help shape the mindset that gave rise to violence and repression against women. Similarly, experienced by Afghan women and children are reflected by the character of Parvana's daughter.

Through the main corpus of the novel of Parvana Trilogy which becomes the examples of the cases that are common and experienced by women and children in Afghanistan this research is done. The 
selection ofthe corpuswhich are three novels based on Afghanistan is related to the background of researchers who are doing research on the works of Middle Eastern writers, one of them is Afghanistan. As one of the countries in the Middle East with a majority Muslim population, Afghanistan has similarities with Indonesia in several aspects, such as the religion of most people, patriarchal culture and ethnic or ethnic diversity which, of course, contribute in some ways to the creation of different mindsets, visibility and social system prevailing in society. This research is done by a qualitative data analysis method and the theory of violence and framing analysis will be used to analyze those violences.

This study became the continuous research centered on gender and women's studies which have been conducted by the researchers. Several studies have taken the corpus of research by Afghan diaspora writers (Agustina, 2010, 2015a, 2015b, 2015c, 2016). Women also need to be given space to actively contribute in the public sphere and have parallels with men. There are many things that can be learned from the novel Parvana Trilogy as these three novels achieve the international success, but we set the limits to examine the violence often experienced by Afghan women during the Taliban regime's rule. For those reasons, based on the background that has been described above, the problems were formulated on how the author's narrative strategy in exposing violence against women in the Parvana Trilogy and what aspects caused the rise of violence against women in Afghanistan?

Some of the researches have done by the previous researches related with one of the Parvana Trilogy or the Parvana Trilogy themselves. Lampert (2007) mentioned that Parvana and her friends' ethnicity is central to the book, but there is no hint of what would be a more contentious allegiance to Islam, consequently the discourses of good and evil as directly related to Islam are avoided in these books. She also convinced that the field of children's literature criticism also support the understanding that childrens' books play a role in the production of identity. Raina (2009) saw the Parvana Trilogy through Postcolonial perspective to observe how Muslims are portrayed within adolescent and children's literature in the United states. She examined children's and adolescent literature published and distributed in the United states that represent Muslims to identify the representations of these cultural 
groups in the books. Through the Trilogy Parvana, she saw literature allows children to experience life in new ways, to reach beyond their personal physical experiences toward new possibilities. Canadian Women for Women in Afghanistan (2006) have done the research and stated that through the portrayal of Parvana and her friends, education is also a major concern for Afghani women. Education is seen as a priority in empowering women in Afghanistan and as an instrument from social change. The education of women has a direct positive impact on the physical and emotional health of the family as well as on national social-economic development. It is because Afghanistan has one of the lowest literacy rates in the world as $15 \%$ for women and $47 \%$ for men. Another writing wriiten by Marshall and Sensoy (2009) mentioned that Trilogy Parvana are framed and packaged to sell in a marketplace at a particular moment when military interventions are centered on Afghanistan and other predominantly Muslim countries. The way Parvana cut their hair and disguise themselves as boys showing the cross-dressing that become anti-mainstream of the portraying of Afghan women and girls whose wearing burqa. This style draws heavily on Western ideas that girls should be unfettered by the requirement to cover themselves, and the author present this type of transformation as the only humane alternative to wearing a burqa and the only way to travel safely outside the domestic sphere. Furthermore, Romylos (2016) stated that Westeners may form very negative perceptions of Islam and Muslims, so the consequence is that all Muslims are stereoptyped as being fundamentalists, terrorists and oppressing their women. Thus knowledge construction is manipulated by Western media. The Trilogy Parvana are very different in their portrayals of Muslim girls or women and may be read comparatively.

The main focus of the researchers aredoing a lot of researches on the works of authors who raised the issues of women and children in Afghanistan which is written by the author of the diaspora of Afghanistan and the volunteers who are on duty in the countries in conflict. One of them is becoming the complements of the road map of the research that has been done. 


\section{B. DISCUSSION}

\section{TRILOGI PARVANA: A CASE OF SIDE EFFECT OF WAR}

The selection of the corpus of this research on the novel Parvana Trilogy are based on several aspects including they have won several awards, including: Middle East Book Award (2002), Ruth Schwartz Award (2003), Jane Addams Peace Award (2003), Hackmatack Award 2005), Red Cedar Book Award (2005), and Lamplighter Award (2006). The diversity of award achieved proves that the story unraveled in this novel trilogy has tremendous value and deserves to be used as a data source.

In this text, as the main character is a girl named Parvana and also her friend, Shauzia who experienced the up and down of life as a result of the various conflicts and wars that led to Afghanistan becomingthe a country that until now has not been separated from the various conflicts that ensnare. An uncertain and gripping life makes Afghanistan vulnerable to exposure to repression and chaos in various parts of Afghanistan.

In the 1960s, Afghans lived in a comfortable and peaceful situation when the invasion of the soviet Union had not occupied the country yet or when ethnic, civil, and Taliban conflict had not ruled the country yet. The lives of Afghan women and men were still free from all forms of rules that imprison their lives in the future. At that time the women were fashionable using short skirts. There were also lots of nice cars and various liberal lifestyle. The situation also looked peaceful, safe, and prosperous. That is inversely proportional to the condition of Afghanistan after exposure by war and under the rule of the Taliban regime.

After the conflict among the ethnics and also the Civil War, newly formed Islamic militia, the Taliban, rises to power on promises of peace. Most Afghans, exhausted by years of drought, famine and war, approve of the Taliban for upholding traditional Islamic values. The Taliban outlaw cultivation of poppies for the opium trade, crack down on crime, and curtail the education and employment of women. Women are required to be fully veiled and are not allowed outside alone. Islamic law which named by Syar'i Islam is enforced via public executions and amputations. The United States refuses to recognize the authority of the Taliban.The harshness of the Taliban in applying the rules and the ban published in 
the decree left Afghans imprisoned within their own country. As a result many are displaced and seek political asylum to various countries in all corners of the world.

After the defeat of the Taliban and forced to leave Afghanistan on December 7, 2001 the life and peace of the country of Afghanistan has never materialized to date. Figures of poverty, hunger, illiteracy and lack of decent health and housing facilities are becoming big jobs for the current government authorities. Girls' dropout rates are still very high in secondary schools and the country's adult literacy rate, $39 \%$ over the age of 15 can read and write, is one of the lowest in the world (BBCnews, 2014).

Despite the advances, violence against women is still a problem, with beatings, forced marriage and lack of economic support being listed as the top three offences reported by the CSO in 2010. Although the number of cases appears to be going down, the report also notes a new form of violence - prevention of women from taking part in social activities. In 2010, Afghanistan had the lowest gross national income per head of population among the developing countries in Asia, well below Bangladesh and Sri Lanka(BBCnews, 2014).

The two photographs below show a comparison of Afghan women's lives in the 1960s and after their country under the Taliban regime. Women's lives are really very drastic and totally changed. In picture 1, Afghan women were wearing modern Western style. They can also move to go to school freely, work and actualize in the public sphere. Such a frontal shift seen in picture 2, Afghan women must obey the rules and regulations of the Taliban regime to wear burqa. Burqa is a loose garment covering the entire body and having a veiled opening for the eyes, worn by Muslim women (Thesaurus dictionary).

The use of burqa for some women in the world who do not use this form of clothing is considered a torture, but for others it does not. The counterfeit feminists will, of course, see the use ofburqa required or obliged to violate the human rights of women, on the contrary the pro will not question it. 


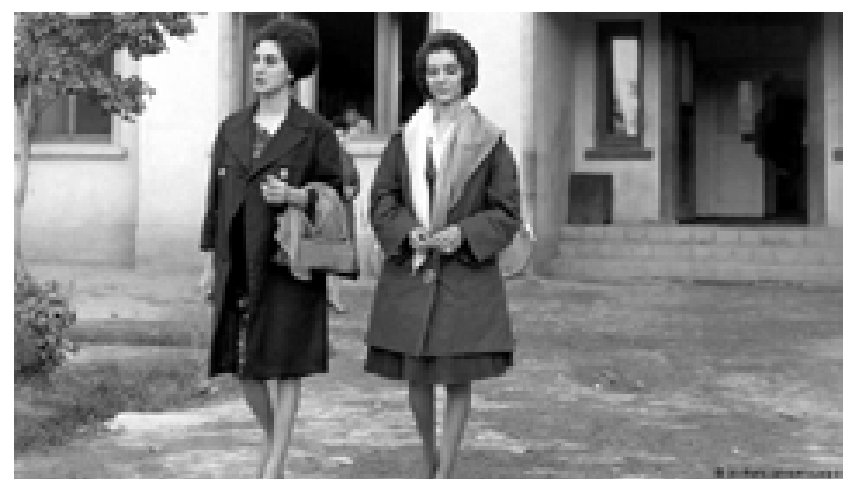

Picture 1: Afghanistan Women's style on October 1962

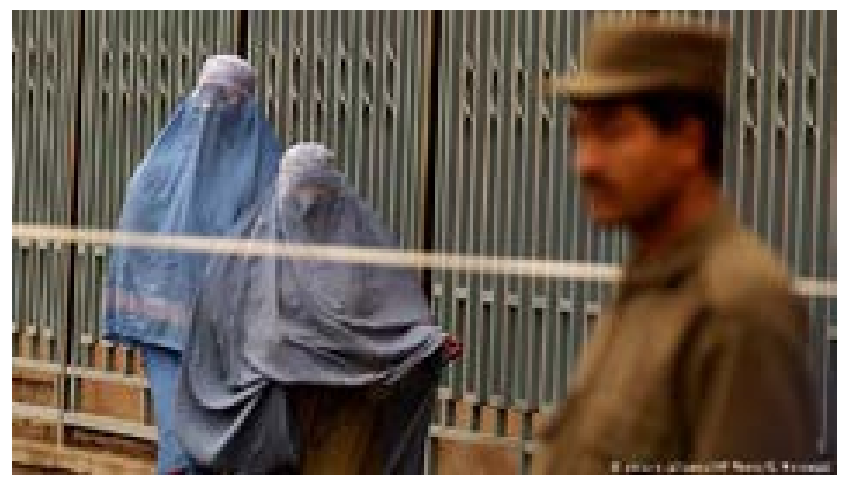

Picture 2: Afganistan women wearing burqa

\section{The War of Afghanistan: The Arise Of Social Problems}

There were 3331 cases of violence recorded and classified into four different types of violence, namely physical, verbal and psychological, economic and sexual violence. Some of the instances could not been assigned to one of these types and were regrouped under the category 'other instances of violence'. The data shows that 1051 individuals have experienced violence in the covered 6 months. All of them experienced at least two types of violence.Social problems that arise as a result of a prolonged war until now no doubt cause suffering both in terms of psychological as well as on the fulfillment of basic daily needs. Some of the social problems which become the burden for the official government of Afghanistan are human trafficking, violence toward women, abuse and neglecting the children, poverty, and underage marriage (Hasrat, 2012).

Mostly the social problems arose and became worse as the side 
effect of conflict among the ethnics issues, civil war, and the Taliban rezim. One of the problems happened in Afghanistan was caused by the gender's inequality and the construction of patriarchy culture legitimated in many aspects of Afghanistan people's life. Gender inequality and patriarchy construction also give the contribution to cause the social problems there. There were many women and children suffered and neglected and live under the poverty and homeless. Moreover, those conditions became the trigger to live as refugees spreading in Pakistan and neighborhood countries.

Many people do not understand the link between gender and sexuality yet and thus create many gender imbalances in our society. Sex is a person's biologically determined as female or male according to certain identifiable physical features which are fixed. Women's marginalisation has often been seen as 'natural' and a fact of their biology. However these biological differences cannot explain why women have less access to power and lower status than men. To understand and challenge the cultural value placed on someone's biological sex and unequal power hierarchies, we need the relational concept of 'gender'. Meanwhile 'Gender' is how a person's biology is culturally valued and interpreted into locally accepted ideas of what it is to be a woman or man. 'Gender' and the hierarchical power relations between women and men based on this are socially constructed, and not derived directly from biology (Baden, 2000). Gender identities and associated expectations of roles and responsibilities are therefore changeable between and within cultures. Gendered power relations permeate social institutions so that gender is never absent.

Understanding those have not been properly understood is a bit much to help shape the mindset that gave rise to violence and repression against women.Across the world, women are treated unequally and less value is placed on their lives because of their gender. Women's differential access to power and control of resources is central to this discrimination in all institutional spheres, for instance: the household, community, market, and state (Baden, 2000).

Gender violence occurs in both the 'public' and 'private' spheres. It happens in virtually all societies, across all social classes, with women particularly at risk from men they know. Official figures are scarce, and 
under reporting is rife, especially when the violence involves another family member. Violence againts women, and particularly systematic rape, has frequently been used as a weapon of war againts particular ethnic groups or entire population.

\section{Women And Children: The Worst Victims}

Women in many places in the Third World have been formed or socially constructed "only" as a wife and mother whose primary duty is at home raising children and taking care of her families. The existing tradition commands women to complete domestic work, housework and maintain family life. While public works to determine the life of society and earn a living handed over to men (Mangun, 2002: 43). Similarly, in Afghanistan, social construction of society perpetuates a patriarchal culture that considers taboo women to be active in the public sphere.

Seeing the lives of Afghan women in the 1960s when they had the freedom to move in the public sphere, went to school and worked in comparison to the era in which the Taliban regime came to power certainly had drastic changed. Working for women is a multiple manifestation, among them self-esteem, pride, trust in personal ability, inner ability and in turn has an effect on the existence of a certainty of life that is more meaningful in the present and the future. Given the patterns and habits that enable them to become independent women, of course life in refugee camps is not easy.

Additionally, women were no longer in control of their life decisions. The Taliban encouraged girls under the age of 16 to get married. "Amnesty International reported that 80 percent of Afghan marriages were considered to be by force" (PBS, 2011). The Taliban appointed a violent religious police force, who often would beat women who violated the Taliban code which regulated the behavior of women. Some of the violations which warranted a beating included a woman exposing her ankles, laughing too loud, wearing shoes that made noise when walking, and/or wearing the wrong type of burkha. No due process was followed when these violations were punished, and the beating often occurred on site as soon as the police officer recognized the violation (PBS, 2011).

Women suffered violence not only from the Taliban forces, but from their biological relatives and their husbands. This violence was only reinforced by the powers in authority. Often militia forces would contribute 
to the violence. "In some instances, female members of the family have a role in upholding patriarchal structures, and may also commit violence" (Amnesty International, 2016). When alleging rape, women found it extremely difficult to convict a suspect. As a plaintiff, a woman had to find four male witnesses to provide testimony corroborating the story of the woman. "If they failed to provide this testimony, they faced flogging or even stoning in the case of adultery" (PBS, 2011).

Those that attempt to defend the women who have fallen victim to violence in Afghanistan have found great difficulty themselves. Human rights advocates and teachers of women continue to face harassment, intimidation, and even violence, with greater danger for minorities and women. "For example, in June 2007 two gunmen opened fire on schoolgirls outside of Kabul, shooting six and killing two, in what was apparently a politically-motivated attack against female education" (Amnesty International, 2016).

\section{Higlight Trilogi Parvana In The Frame Analysis}

This research will highlight the Ellis' Parvana Trilogy as a literary work that carries the theme of Afghan women and children as a result of the chaotic condition of their country after many conflicts and civil wars. In the media frame, in this case are the three novels she wrote, voicing the condition of the oppression of women and children in which the state that should act as protector and public servant can not perform its functions and roles to the maximum so that the author through these three novels feel the need to show the difficult situation experienced by Afghan women and children.

Framing theory suggests that how something is presented to the audience which is called as the frame influences the people's choices about how to process the information. Frames are abstractions that work to organize or structure the message meaning. The most common use of frames is in terms of the frame the news or media place on the information they convey. They are thought to influence the perception of the news by the audience, in this way it could be construed as a form of second level agenda-setting - they not only tell the audience what to think about (agenda-setting theory), but also how to think about that issue (second level agenda setting, framing theory). According to Goffman (1974), people interpret what is going on around their world through their 
primary framework. This framework is regarded as primary as it is taken for granted by the user. Its usefulness as a framework does not depend on other frameworks.Goffman states that there are two distinctions within primary frameworks: natural and social. Both play the role of helping individuals interpret data. So that their experiences can be understood in a wider social context. The difference between the two is functional.

Violence against women does not come down to the citizens of Afghanistan from those who accept it in the government. This sort of violence is widely accepted and practiced in the community. "Abusers are rarely prosecuted; if cases are prosecuted, the accused are often exonerated or punished lightly" (Amnesty International, 2016).Violence against women is one of the most serious human rights issues in Afghanistan. Eventhough the importants have been made in different areas of such as education for women and girls, health and participation of women in civil and political activities the last decade, deep-rooted cultural and social issues still exist against realization of and their freedom in many parts of our country. Violence against women is one of the serious violations (Saramad, 1392). Violence is pervasive throughout Afghanistan. It has diverse manifestations in different parts of the country. Violence against women is widespread and deeply-rooted as well as asacute. The violence which scars the lives of a huge proportion of Afghan women and girls is rooted in Afghan culture, customs, attitudes, and practices. Afghan women have limited freedom to escape the norms and traditions that dictate a subservient status for females (UNAMA, 2009).

Media is a construction agent. In a constructionist view, the media is not just a free channel, it is also the subject that constructs reality, complete with views, bias and parenting. Through the language used and through the news, the media can frame events with a certain frame that ultimately determines the audience must see and understand events in particular eyeglass (Eriyanto, 2009: 15). In the context of this research corpus in the form of a novel, an event, issue or phenomenon can be an interesting thing. Authors can shape and determine whether an event or reality can be made news. And all forms of news and issues about Afghanistan would be very interesting to be a writing theme.

Each media has different perspectives and conceptions of seeing an event or reality. They have different views on media and news texts. 
Framing analysis method is used to examine how the contents of text displayed to audiences in the study of communication science can be done and researched. Framing analysis is the analysis used to see how the media construct reality. Framing analysis is also used to see how events are understood and framed by the media (Eriyanto, 2009: 10). In this study, framing model used is from Entman. The framing concept in Entman's view, consistently offers a way of expressing the power of communication text. Framing analysis can explain in the proper way the influence of human consciousness that is urged by the transfer or communication of information from a novel though. Entman (2007) sees framing in two major dimensions: issue selection and emphasis or highlighting certain aspects of a reality or issue. Framing is run by the media by selecting certain issues and ignoring other issues.

In the first novel The Breadwinner (2000), Ellis necessarily had to deliver a considerable amount of information to the reader about Afghanistan, its history and current living conditions. She dressed up like a boy so she could walk freely. She would make some sales on the market and read letters that were brought by illiterate Taliban. She also recognized her friend that also dressed up like a boy and the two of them decided to come up with a plan to make some money.The book deals with some important problems such as women not being able to walk freely on the street, being forced to cover up their whole body, being submissive to men and constantly living under a fear of getting raped. Many people lost their family and went through horrible things, such as Homa, that saw her family dead on the street but had to leave them and run to save herself. They dreamt of a better life and even started running away without knowing where they are going.

Meanwhile in the second novel titled Parvana's Journey (2002), the writer told Parvana's life starting from her thirteen years old. She started on her search for her mother and siblings in war-ravaged Afghanistan. Parvana's adversary is the landscape, both political and physical: the fearful reign of the Taliban still looms, bombs fall from the sky, minefields block her path; food, water, and shelter are always scarce. The portraying is about a girl's survival. She just became the resourceful hero. The sadness part is because there is not destination for Parvana, no home at all. She can only hope that somehow her meandering path will cross with her displaced family's.Parvana's Journey contains scarcely 
a historical or political reference. The result is a swifter opening, and a story focused more on one character's physical struggles than on a geopolitical situation. This is a book that will open children's perspectives to the larger world - a glimpse that will almost certainly make readers grateful for what they have.

The last novel of Trilogy of Parvana is Mud City (2003). It is the final volume in Deborah Ellis's Afghan trilogy, follows 14-year-old Shauzia, Parvana's best friend, into a refugee camp in Pakistan. Having fled an arranged marriage in Kabul, Shauzia becomes little more than a gopher for Mrs. Weera, her former phys-ed teacher, who's in charge of the widows' compound at the camp and a tireless worker for a better future. But Shauzia still dreams of escaping to France and putting the horrors of her life behind her, so she leaves the camp with her dog Jasper and tries to fend for herself on the dangerous streets of the nearby city of Peshawar. When she's wrongfully accused of theft and thrown into prison, she's rescued by a well-meaning American family, but that sours when she tries to emulate their generosity and, instead, incurs their disapproval. Returning to the camp, Shauzia slowly discovers that, like Mrs. Weera, she likes helping people and can make a difference in their lives. She doesn't give up her dreams but realizes that they can wait until she's ready for them.

As a result of the media framing, the three novel Parvana Trilogy can be a tool to continue to propagate the reader's concern for the fate of the repressed, violence, and gender inequality of the Afghan population. In the framing analysis framework, the depictions of Afghan women and children are seen from the position of those who have always been the most severely affected by the violence perpetrated by the ruling Taliban regime. The media in this case is the writer is trying to raise issues of violence and poverty in Afghanistan to draw international public awareness of the social and humanitarian issues in Afghanistan.

\section{Gender Relation In Indonesia And Afghanistan}

Gender equality in Indonesia when compared with gender equality in Afghanistan is of course a more advanced level especially for the opportunities and roles of women in the domestic sphere. Various professions can be done by Indonesian women even up to the highest policy-making order. Noted, Indonesia's first female president Megawati 
Soekarnoputeri, who governed Indonesia in 2002-2004 incised historical record of the role of women leaders in Indonesia. The struggle of Afghan women to be able to play an active role in the domestic sphere, free to go to school and continue to university level still have to process and be patient to really become an independent state which apart from all forms of invasion, repression and colonization. With the opening of opportunities for Indonesian women to be able to access information, selecting professions, continuing to higher education will contribute ideas and ideas to become an advanced Indonesian country that can compete with the big countries in the world.

Afghanistan can imitate Indonesia in providing the widest possible space and opportunity for its women to actively contribute in various fields. No more gender inequalities affect the physical and psychological repression of women. As a country with a Moslem majority, Afghanistan must hold on to the Qur'an and the Sunnah of the Prophet. Islam has abolished discrimination on the basis of sex. The principle of gender equality and justice in Islam is contained in the holy book of the Qur'an. In the teachings of Islam is not known any gender issues that adversely affect women. Islam even establishes women in an honorable position, having the same degrees, dignity and equal with men.

With a very clear concept in Islam that Islam is a divine religion as well as a religion of humanity and society. In the view of Islam, human has two capacities, namely as a servant and as a representation of God (khalifah) without distinction of sex, ethnicity, and color of skin. Islam mandates human to pay attention to the concept of balance, harmony, and wholeness for both human and human beings with their natural environment.

Unequal gender relations in many Islamic countries based on the often-debated concepts of Islamic law are more recently understood as the laws of fiqh. In the time of Prophet Muhammad SAW, what is meant by Islamic Shari'ah is everything that Allah revealed to His Messenger, Muhammad SAW in the form of revelation contained in the Qur'an and the sunnah of the Prophet. Shari'ah in this sense is different from fiqh. Shari'ah is a holy and absolute Islamic law, whereas fiqh can be a jurisprudence. In other words, the truth is not absolute.

Prophet Muhammad SAW just left the Qur'an and Sunnah. 
Companions compile verses that are scattered, into one mushaf. At the time of tabi'in in the 3rd century or $8 \mathrm{AD}$, newly collected hadith that spread to the books of hadith. Then it is felt that what is in the book of the Qur'an and hadith is not enough to respond to various times. Then do the interpretations of the Qur'an or Hadith. That interpretation is recorded in the Tafsir books or the fiqh books that we now know. According to Mulia (Swara Rahima, 2001: 15), the jurisprudence book on marriage, for example, is one example of the variation of views in understanding and interpreting the hadiths uttered by the Apostle. The issue is whether the interpretation becomes an absolute thing or not. The difference in interpretation in understanding the Qur'an and Hadith has actually occurred in the time of the Prophet. The Companions understood the teachings of Islam according to the level of intelligence, the proximity to the Prophet and various other factors. Beautifully, the Prophet Muhammad tolerated these differences of views without blaming anyone (Viviani, 2001: 15).

Prophet Muhammad was sent to a very patriarchal society and there was almost no place for women. The Prophet came to liberate man from a system of tyranny, including liberating women from unjust cultural bondage. The Prophet began to establish an inheritance for women, although the amount is not yet comparable with men. At that time, the determination of inheritance rights for women was a very progressive act. Because, let alone have inheritance rights, women at that time is a commodity inherited. This is just one example of how the Prophet raised the dignity of women. Reflecting on the struggle and spirit of the Prophet to empower and equate the position of women and men, Afghanistan must also be able to fight for and elevate women's dignity in the public sphere by providing opportunity and also the right to take part in making Afghanistan a great and independent nation. By looking at friendly countries, Indonesia should also be able to contribute to the importance of providing space and opportunities for Afghan women to actively contribute to the advancement of their peoples, so that gender equality will truly enable the conditions of a state free from repression and violence against women. 


\section{Conclusion}

Our concern as a fellow country with a large majority of the population adheres to Islam towards Afghanistan should be sought. The presence of good novels written by Afghan diaspora writers and volunteers who have lived there with the theme of violence and oppression that threaten the safety of women and children make readers aware. The Parvana Trilogy that is present among the novels that carries the story of the pain of the Afghan population complements the reader's knowledge of the tragedy of humanity that takes place in Afghanistan.

The uncertain conditions, the loss of family and property and the opportunity to become an independent human being are the impacts of civil wars, inter-ethnic conflicts to the mastery of the Taliban regime. Women and children abandoned, they have to bear the consequences of the loss of the head of the family who became the backbone of the family. As a result of that, social problems such as human trafficking, disguises to be boys in order to avoid torture by Taliban are often carried out by Afghan children, and life as refugees who are not guaranteed safety from bombs and mines making the impact of the chaos in Afghanistan unnumbered.

In the framing analysis, TheParvana Trilogy which tries to raise the issue of violence, poverty and helplessness experienced by Afghan children are trying to be lifted. The media has tremendous potential to influence that can shape opinion for a country's change.Gender inequality, repression and poverty which is controlled by the construction of patriarchy culture dominate all of those aspects in Afghanistan. Huge changes are really needed to be done in Afghanistan to embody the peacefull country and give the protection and prosperity for all of the nations.

To summarize, the capacity to use violence is in many societies and throughout much of history as an integral part of the male habitus. The use of physical or structural, collective and or without individual violence against other men, women and children can serve different social and individual functions, as demonstrated above. This does not mean that the use violence is natural or that all men use violence. On the contrary, men have resisted public and private pressure to use violence throughout history. Young men have evaded conscription to the army or fled from 
fighting, as the history of traitors, cowards and deserters - names they have been called in order to stigmatise them. Men have chosen not to join the guerrilla or militia and they have refrained from using violence in the domestic sphere. Men have also been actively supporting peace and nonviolent movements at all times. Furthermore, in order to sustain a culture of violence, both gender have to contribute. 


\section{REFERENCES}

Agustina, Hiqma Nur, 2010,. "Representasi Perempuan Afghanistan dalam Novel MyForbidden Face dalam Kaitannya dengan Relasi Gender". Jurnal Ilmu Pendidikan dan dan Ilmu Sosial (JIPIS) Volume 11, No. 2, Januari-Juni 2010. Lembaga Penerbit FKIP Universitas Islam Syekh-Yusuf.

Agustina, Hiqma Nur, 2015a, "The Kite Runner: My Passion of Literature" paper and prosiding presented in the International Conference on Social Sciences and Humanities 2015, Bali, May 4-5, 2015.

Agustina, Hiqma Nur, 2015b, "Dominasi Konflik Antar-etnis dalam The Kite RunnerKarya Khaled Hosseini" paper and prosiding presented in the Seminar Nasional Bahasa dan Sastra (Senabastra) VII di Universitas Trunojoyo Madura, June 10, 2015.

Agustina, Hiqma Nur. 2015c, "Inspiring Woman Against the Terror in A Dressmaker from Khair Khana" paper dan prosiding presented in The 4th International Multi-Conference on Humanities, Law, Literature and Management 2015 in Pattaya, Thailand, June 1819, 2015.

Agustina, Hiqma Nur, 2016, "When Desperate and Guilty Feeling Destroy Humans' Life in And The Mountains Echoed By Khaled Hosseini" paper and prosiding presented in International Conference on Language and Literature (ICALL) 2016. Kuala Lumpur, Malaysia May 9-10, 2016.

Amnesty International, 2016, Their Lives on the Line. Women Human Rights Defenders in Afghanistan Spring 2016-Activist Toolkit. Retrieved from: https://www.amnestyusa.org/pdfs/ AfghanWomensRightsDefenders_Toolkit_Mar2016.pdf

Baden, Sally \& Hazel Reeves, 2000, Gender and Development: Concepts and Definitions. UK: Institute of Development Studies.

BBCNews. Afghanistan. Before and after the Taliban. April 2nd, 2014. Retrieved from: http://www.bbc.com/news/world-asia-26747712. 
Canadian Women for Women in Afghanistan, 2006, Understanding Human Rights in Afghanistan. Red 1. Resource Booklet.

Retrieved from: file://C:/Users/User/Documents/Pindahan $\% 20$ laptop\%20mama/Data\%20Pusataka\%20Trilogi\%20Parvana/R1CW4Wafghan.pdf

Ellis, Deborah, 2011, Parvana. The Breadwinner. Toronto: Groundwoods Books. , 2011, Parvana's Journey. Toronto: Groundwoods Books. , 2011, Mud City. Toronto: Groundwoods Books.

Entman, Robert. M, 2007, "Framing Bias: Media in the Distribution of Power”, Journal of Communication, 57.

Eriyanto, 2009, Analisis Framing, Konstruksi, Ideology dan Politik Media. Yogyakarta: LkiS.

Giddens, Anthony, 1995, The Constitution of Society: The Outline of The Theory ofStructration. UK: Policy Press Cambridge.

Goffman, Erving, 1974, Frame Analysis: An Essay on the Organization of Experience. New York: Harper \& Row.

Hasrat, M. H. \& Alexandra Pfefferle, "Violence Againts Women in Afghanistan. Biannual Report 1391. Kabul: Afghanistan Human Rights Commission". Retrieved from:http://www.aihrc.org.af/ media/files/VAW_Final\%20Draft-20.12.pdf.

Lampert, Jo, 2007, "Dissertation. The Whole World Shook: Shifts in Ethnics, National and Heroic Identities in Children's Fiction About 9/11". New Zealand: Centre for Learning Innovation: Queensland University of Technology.

Mangun, Nuhdiatul Huda, 2002, "Perempuan Tulang Punggung Ekonomi Keluarga Pasca Konflik (Kerusuhan) Poso". Jurnal Perempuan Volume 24. Juli 2002. Jakarta: Yayasan Jurnal Perempuan.

Mulia, Musda, 2001 , "Syari'at Islam Tidak Mungkin Merendahkan Perempuan, dalam Swara Rahima No. 2. Th. I, Agustus. 
Raina, Seemin, 2009, "Dissertation. Critical Content Analysis of Postcolonial Texts: Representation of Muslims within Children's and Adolescent Literature", Arizona: The

Viviani, Nefisra, 2001. Wawancara dengan Dr. Musda Mulia, APU. "Syari'at Islam Tidak Mungkin Merendahkan Perempuan"dalam Swara Rahima. No. 2 Th. I, Agustus.

Marshall, Elizabeth \& Özlem Sensoy. "Save the Muslim Girl!" in Rethinking Schools. Volume 24, No.2 - Winter 2009/2010. Retrieved from: https://www.rethinkingschools.org/articles/h1save-the-muslim-girl-h1

Burqa. Dictionary.com. Retrieved from: http://www.dictionary.com/ browse/burqa

"Image Perempuan Afghanistan Dulu dan Sekarang". Retrieved from: http://www.dw.com/id/perempuan-afghanistan-dulu-dansekarang/g-18625883

PBSNewsHour. “A Histrorical Timeline of Afghanistan”. May 4, 2011. Retrieved from: http://www.pbs.org/newshour/updates/asia-janjune11-timeline-afghanistan/

Romylos, Salome. "Critical literacy: The encounter between Western secularism and Islamic spirituality in selected young adult novels - An approach". AOSIS Publishing Vol. 37 No. 1 (2016). Retrieved from: http://www.literator.org.za/index.php/literator/ article/view/1260/2162

Saramad, Hussain Mohammad \& Latifa Sultan, 1392, Violence againts Women in Afghanistan. (The first six months of the year-1392). Retrieved from: http://www.refworld.org/pdfid/5297436c4.pdf

UN Assistance Mission in Afghanistan (UNAMA) \& the Office of the UN High Commissioner for Human Rights (OHCHR). (2009)."Silence is Violence: End the abuse of Women in Afghanistan". Kabul. Retrieved from: http://www.ohchr.org/Documents/Press/VAW_ Report_7July09.pdf 